\title{
UVB-3 I I nm phototherapy and NAD(+)/NADH metabolism in keratinocytes in patients with psoriasis
}

\author{
Fototerapia UVB-3 I I nm a metabolizm NAD(+)/NADH w keratynocytach \\ u chorych na łuszczycę
}

Małgorzata Bernacka, Agata Liszewska, Ewa Robak, Anna Woźniacka, Jarosław Bogaczewicz

Department of Dermatology and Venereology, Medical University of Lodz, Poland

Klinika Dermatologii i Wenerologii Uniwersytetu Medycznego w Łodzi, Polska

Dermatol Rev/Przegl Dermatol 2018, 105, 710-715 DOI: https://doi.org/l0.5 I /4/dr.2018.80839

\author{
CORRESPONDING AUTHOR/ \\ ADRES DO KORESPONDENCJI: \\ lek. Małgorzata Bernacka \\ Klinika Dermatologii \\ i Wenerologii \\ Uniwersytet Medyczny \\ w Łodzi \\ pl. J. Hallera $1 / 6$ \\ 90-647 Łódź, Polska \\ tel.: +48426867981 \\ faks: +48 426884565 \\ e-mail: malgosia.bernacka@interia.pl
}

\begin{abstract}
Narrow band (311 nm) UVB phototherapy is established treatment for psoriasis. DNA is a target for UVB via formation of cyclobutane pyrimidine dimers, which trigger loss of dendritic cells and macrophages, and inhibit CD4+ and CD8+ T cells. UV causes the formation of thymine dimers, which activate nuclear enzyme poly(ADP-ribose) polymerase. The fact that poly(ADP-ribose) polymerase utilizes nicotinamide-adenine dinucleotide (NAD) explains NAD decreases after UV irradiation. NADH regulates transcriptional repressor carboxyl-terminal binding protein, whereas $\mathrm{NAD}(+)$ is a co-substrate in deacylation reactions, engaged in genomic silencing. Hyperproliferation of psoriatic keratinocytes requires NADH during oxidative phosphorylation. In one study the NADH fluorescence (reflecting NADH amount) was reduced in psoriatic lesions. $\mathrm{NAD}(+)$ used topically was as effective as $0.1 \%$ anthralin. Spectrophotometry enables real-time measurements of NADH fluorescence in vivo in the epidermis and points out a new direction for application of biophysics in medicine.
\end{abstract}

\section{STRESZCZENIE}

Fototerapia wąskim pasmem UVB (311 nm) jest uznaną metodą leczenia łuszczycy. Molekularnym punktem uchwytu fototerapii UVB jest DNA poprzez tworzenie się dimerów cyklobutanopirymidynowych, które wyzwalają utratę komórek dendrytycznych i makrofagów oraz hamują komórki CD4+ i CD8+. Promieniowanie UV powoduje wytwarzanie dimerów tymidynowych aktywujących jądrową polimerazę poli(ADP-rybozy) (PARP). Zużywanie przez PARP dinukleotydów nikotynoamidoadeninowych (NAD) wyjaśnia zjawisko zmniejszania się zawartości NAD po naświetlaniu UV. NADH reguluje represorowe białko transkrypcji wiążące koniec karboksylowy, natomiast $\mathrm{NAD}(+)$ służy jako kosubstrat w reakcjach deacylacji, które mają udział w wyciszaniu genomu. Hiperproliferacja keratynocytów w łuszczycy wymaga zużywania NADH podczas fosforylacji oksydacyjnej. W jednym z badań stwierdzono obniżoną fluorescencję NADH (odzwierciedlającą zawartość NADH) w zmianach łuszczycowych. Stwierdzono, że $\mathrm{NAD}(+)$ stosowany miejscowo jest równie skuteczny co $0,1 \%$ antralina. Spektrofotometria umożliwia pomiar fluorescencji NADH w naskórku 
in vivo w czasie rzeczywistym i wskazuje kierunek zastosowań biofizyki w medycynie.

Key words: ultraviolet, psoriasis, nicotinamide-adenine dinucleotide, spectrophotometry.

Słowa kluczowe: ultrafiolet, łuszczyca, dinukleotyd nikotynoamidoadeninowy, spektrofotometria.

Psoriasis is a chronic inflammatory disease that can occur at any age with the prevalence ranging from $0.09 \%$ in the United Republic of Tanzania [1] to $11.4 \%$ in Norway [2]. Although the exact etiology of this entity is still not completely understood, the pathogenetic background of psoriasis embraces excessive proliferation of keratinocytes, elongation of dermal blood vessels, and infiltration of the skin with T cells [3]. Hyperproliferation of keratinocytes results in their incomplete maturation, which is manifested as incomplete synthesis of tonofibrils, and a loss of stratum granulosum [4]. While under normal conditions the transit time of keratinocytes from the basal cell layer to the stratum corneum takes approximately 28-30 days, in psoriasis it takes 3-5 days [4]. The aforementioned data constitute the scientific background for the use of ultraviolet phototherapy in inhibition of keratinocyte proliferation in psoriasis. Carrascosa et al. revealed a reduction in the expression of keratinocyte proliferation markers, such as Ki-67, cyclin A, and cyclin B, after using narrow band UVB (311 nm) [5]. Currently, phototherapy using narrow band UVB is established treatment for psoriasis [6]. Although the exact mechanisms that underlie successful phototherapy for psoriasis are not fully elucidated, its effectiveness is attributed to action on keratinocytes and immune cells [7]. Undoubtedly, DNA is a target for phototherapy via formation of cyclobutane pyrimidine dimers, which trigger loss of dendritic cells and macrophages [8], along with inhibition of the expansion of effector CD4+ and CD8+ T cells [9]. UV radiation was found to cause direct DNA damage, resulting in the formation of thymine dimers, which induces activation of the nuclear enzyme poly(ADP-ribose) polymerase (PARP) [10]. Direct DNA damage occurred within the first 15 seconds to 5 minutes after UVB irradiation and was responsible for immediate PARP activation, as a dynamic and flexible response that could be targeted to the site of specific DNA damage caused by UV [10]. PARP is a Zn-finger nuclear protein activated by DNA breaks and utilizes nicotinamide-adenine dinucleotide (NAD), as a substrate to catalyze the synthesis of (ADP-ribose) polymers
Łuszczyca jest przewlekłą chorobą zapalną, która może pojawić się w każdym wieku. Częstość występowania choroby wynosi od 0,09\% w Zjednoczonej Republice Tanzanii [1] do 11,4\% w Norwegii [2]. Dokładna etiologia łuszczycy wciąż nie jest do końca poznana, a jej patogeneza obejmuje nadmierna proliferację keratynocytów, wydłużenie naczyń krwionośnych skóry i naciekanie skóry przez limfocyty T [3]. Hiperproliferacja keratynocytów wynika z ich niepełnego dojrzewania, co prowadzi do niekompletnej syntezy tonofibryli i utraty warstwy ziarnistej naskórka [4]. W warunkach prawidłowych czas przejścia keratynocytów z warstwy podstawnej do rogowej wynosi ok. 28-30 dni, natomiast w łuszczycy trwa 3-5 dni [4]. Powyższe spostrzeżenia stanowią podstawę naukową do stosowania fototerapii UV w celu hamowania proliferacji keratynocytów w łuszczycy. W pracy Carrascosa i wsp. wykazano zmniejszenie ekspresji markerów proliferacji keratynocytów, takich jak Ki-67, cyklina A i cyklina B, po zastosowaniu fototerapii wąskim pasmem UVB (311 nm) [5]. Obecnie fototerapia przy użyciu wąskiego pasma UVB stanowi uznaną metodę leczenia łuszczycy [6]. Chociaż mechanizmy determinujące skuteczność fototerapii w łuszczycy nie zostały w pełni wyjaśnione, uważa się, że mają związek z oddziaływaniem na keratynocyty i komórki odpornościowe [7]. Nie ulega wątpliwości, że punktem uchwytu dla fototerapii jest DNA, poprzez tworzenie się dimerów cyklobutanopirymidynowych, co wyzwala utratę komórek dendrytycznych i makrofagów [8] oraz hamuje ekspansję efektorowych limfocytów T CD4+ i CD8+ [9]. Stwierdzono, że promieniowanie UV wywołuje bezpośrednie uszkodzenie DNA, powodując tworzenie dimerów tyminy, które indukują aktywację enzymu jądrowego polimerazy poli(ADP-rybozo) polimerazy (PARP) [10]. Bezpośrednie uszkodzenie DNA następuje $\mathrm{w}$ ciągu pierwszych 15 sekund do 5 minut od napromieniania UVB i wywołuje natychmiastową aktywację PARP. Jest to dynamiczna reakcja, która może być ukierunkowana na specyficzne miejsce w uszkodzonym przez UV łańcuchu DNA [10]. PARP jest białkiem jądrowym zawierającym motyw palca cynkowego, aktywowanym wskutek pęknięcia DNA. Wykorzystuje dinukleotyd nikotynoamidoadeninowy 
on nuclear proteins, including PARP itself, causing long branched chains of poly(ADP-ribose) (PAR) [11]. The fact that PARP utilizes NAD explains why the level of NAD drops upon UV irradiation [12]. This cellular response reaches a minimum level 60 min after irradiation, then there is a quick recovery, followed by a slow decrease over the first 24 hours [12]. Two metabolic pathways determine the synthesis of NAD molecules, namely, the deamidated and amidated pathways. The deamidated pathway generates NAD molecules via synthesis from tryptophan, whereas the amidated pathway uses salvaged nicotinic acid [13]. NAD occurs in reduced or oxidized forms, respectively NADH and NAD. The main cellular sources of NADH are provided by glycolysis and the citric acid cycle (Krebs cycle). $\mathrm{NADH}$ molecules are oxidized in the mitochondrial respiratory chain, which is responsible for the synthesis of ATP [14].

Taking into account the aforementioned data, one can assume that the effectiveness of phototherapy could also be attributed to a decrease in NADH level in the cells. It seems reasonable since the proliferation of psoriatic keratinocytes requires consumption of NADH during oxidative phosphorylation and ATP synthesis. In the study of Wollina et al. the NADH fluorescence was found to be reduced in psoriatic lesions [15]. In the search for new antipsoriatic agents $\mathrm{NAD}(+)$ used topically was found to be as effective as $0.1 \%$ anthralin [16]. As a rationale for phototherapy in management with psoriasis, a depletion of NAD induced by UVB would result in inhibition of keratinocyte proliferation. However, there are no studies devoted to the confirmation or rejection of such a scientific hypothesis. On the one hand, one can speculate that increased proliferation and inflammation in the psoriatic lesion is linked with NADH consumption. On the other hand, increased metabolism might be preceded by increased NADH synthesis. However, there are insufficient data in real-time, in vivo noninvasive NADH monitoring in psoriatic skin. Moreover, the role of NADH in psoriasis seems not to be limited to its involvement in cellular respiration, and such a thesis would be an oversimplification. Zhang et al. showed that $\mathrm{NADH}$ is not only the source of electrons for the respiratory chain but can also influence gene transcription, as they demonstrated that NADH regulated the transcriptional repressor carboxyl-terminal binding protein (CtBP) [17]. The authors mentioned above showed that an increase in NADH level resulted in CtBP binding in vivo and enhanced CtBP-mediated repression [17]. They concluded that changes in nuclear $\mathrm{NAD}(+) / \mathrm{NADH}$ ratio allowed CtBP to be used as a redox sensor for transcription [17]. In another study, NAD was found to be involved in
(NAD) jako substrat do katalizowania syntezy polimerów (ADP-rybozy) na białkach jądrowych, w tym również PARP, co powoduje powstawanie długich, rozgałęzionych łańcuchów poli(ADP-rybozy) (PAR) [11]. Zjawisko wykorzystywania NAD przez PARP wyjaśnia zmniejszenie stężenia NAD obserwowane po napromieniowaniu UV [12]. Taka odpowiedź komórkowa osiąga minimalny poziom 60 minut po napromieniowaniu, po czym następuje szybka odnowa i powolna redukcja w ciągu pierwszych 24 godzin [12]. Syntezę cząsteczek NAD determinują dwa szlaki metaboliczne - deamidacji i amidacji. W szlaku obejmującym proces deamidacji cząsteczki NAD powstają na drodze syntezy z tryptofanu, a w szlaku amidacji wykorzystuje się odzyskany kwas nikotynowy [13]. NAD występuje w formie zredukowanej lub utlenionej - odpowiednio NADH i NAD. Do głównych źródeł komórkowych NADH należą: glikoliza i cykl kwasu cytrynowego (cykl Krebsa). Cząsteczki NADH ulegają utlenianiu w mitochondrialnym łańcuchu oddechowym, w którym następuje synteza ATP [14].

Przedstawione powyżej dane sugerują, że skuteczność fototerapii może być skutkiem zmniejszenia stężenia NADH w komórkach. Wyjaśnienie to wydaje się przekonujące, ponieważ proliferacja keratynocytów w łuszczycy wymaga zużywania NADH w procesie fosforylacji oksydacyjnej i syntezy ATP. Wollina i wsp. wykazali, że fluorescencja NADH zmniejsza się w zmianach łuszczycowych [15]. Przy poszukiwaniu nowych leków przeciwłuszczycowych stwierdzono, że stosowany miejscowo $\mathrm{NAD}(+)$ jest równie skuteczny jak $0,1 \%$ antralina [16]. Uzasadnieniem dla fototerapii w leczeniu łuszczycy jest indukowane przez UVB zmniejszenie ilości NAD skutkujące zahamowaniem proliferacji keratynocytów. Nie ma jednak badań pozwalających na całkowite potwierdzenie lub odrzucenie tej hipotezy. Z jednej strony można postulować, że nasilona proliferacja i stan zapalny w wykwitach łuszczycowych mają związek ze zużywaniem NADH. Z drugiej - wzmożenie metabolizmu może być poprzedzone zwiększoną syntezą NADH. Nie ma jednak wystarczających danych pochodzących z nieinwazyjnego monitorowania NADH w czasie rzeczywistym in vivo w skórze łuszczycowej. Ponadto rola NADH w łuszczycy nie jest najprawdopodobniej ograniczona do udziału w procesie oddychania komórkowego, a taka teza byłaby uproszczeniem. W badaniu Zhang i wsp. ustalono, że NADH jest nie tylko źródłem elektronów dla łańcucha oddechowego, lecz może także wpływać na transkrypcję genów. Badacze wykazali, że NADH reguluje represorowe białko transkrypcji wiążące koniec karboksylowy (CtBP) [17]. Wspomniani powyżej autorzy zaobserwowali, że wzrost stężenia NADH powoduje wiązanie CtBP in vivo i nasilenie represji wynikającej z działania CtBP [17]. Stwierdzili, że dzięki sygnalizowaniu zmian w stosunku $\mathrm{NAD}(+) / \mathrm{NADH}$ 
histone deacetylation, which connects metabolism and epigenetic gene regulation such as genomic silencing [18]. In this process, sirtuins utilize NAD(+) as a co-substrate in the deacylation reactions [18]. Therefore in the pathogenesis of psoriasis changes in $\mathrm{NAD}(+)$ and NADH levels could influence gene transcription. However, such studies have not been conducted in vivo in psoriatic lesions so far. In 1951 Thoerell and Chance developed a spectrophotometric method in assessment of alcohol dehydrogenase level, and it was a step forward in the introduction of new techniques in evaluation of the amount of NADH in biological specimens [19]. However, every method has its limitations. Difficulties arise when one needs to differentiate whether measured NADH fluorescence reflects free NADH or protein bound or both. One encounters obstacles when determining cellular sources of NADH: mitochondrial, cytosolic and nuclear. Technically, NAD $(+)$ and NADH should readily transit through nuclear pores. Therefore changes in cytoplasmic levels of NADH imply changes in nuclear levels. Moreover, it is difficult to differentiate NADH from the reduced form of nicotinamide adenine dinucleotide phosphate (NADPH), which is why usually the sum of both molecules is estimated. Currently, it is possible to measure the amount of NADH in vivo in the epidermis, without tissue or cell extractions. The rationale of such techniques relies on the fact that NADH absorbs ultraviolet light (320-380 nm) and emits blue fluorescence in the $420-480 \mathrm{~nm}$ range [19]. In contrast, NAD does not fluorescence. That is why it is possible to assess the NADH level by monitoring the UV absorbance or by detecting the blue fluorescence [19]. The latter is used in the AngioExpert device, which measures the amount of NADH in the epidermis [20]. The AngioExpert enables one to measure in real-time, in vivo, the dynamic NADH status in the epidermis of the forearm skin, as it can assess NADH changes in time in response to blockage (occlusion) of blood flow in the arm artery with the sphygmomanometer (blood pressure meter) followed by its release (reperfusion) [20]. Technically, the AngioExpert measures fluorescence of NADH molecules excited by ultraviolet (UV) radiation of $340 \mathrm{~nm}$ (UVB), and the maximum light penetration of $340 \mathrm{~nm}$ is about 0.3 to $0.5 \mathrm{~mm}$ in the epidermis [20]. That is why the emitted NADH fluorescence at $460 \mathrm{~nm}$ (blue light) is detected and enables measurement of NADH in the epidermis [20]. It seems that more than $90 \%$ of the NADH signal is received from the outermost layer up to $0.1 \mathrm{~mm}$ depth [20]. Typical epidermal fluorescence of NADH recorded in the forearm of a 29-year-old woman during rest in a seated position followed by 100 -second ischemia and reperfusion is shown in figure 1. w jądrze, CtBP może służyć jako wskaźnik redoks przy transkrypcji [17]. W innym badaniu zaobserwowano, że NAD bierze udział w deacetylacji histonów, która łączy metabolizm z epigenetyczną regulacją genów, m.in. $\mathrm{z}$ wyciszaniem genomu [18]. W procesie tym sirtuiny wykorzystują NAD(+) jako kosubstrat w reakcjach deacylacji [18]. Z tego względu w patogenezie zmian łuszczycowych zmiany poziomu NAD(+) i NADH mogą wpływać na transkrypcję genów. Dotychczas nie przeprowadzono jednak badań in vivo $\mathrm{w}$ zmianach łuszczycowych. W $1951 \mathrm{r}$. Thoerell i Chance opracowali metodę spektrofotometryczną do oznaczania stężenia dehydrogenazy alkoholowej, która stanowiła krok naprzód we wprowadzaniu nowych technik do oceny ilości NADH w próbkach biologicznych [19]. Każda metoda ma jednak swoje ograniczenia. Trudności pojawiają się, gdy niezbędne jest rozróżnienie, czy zmierzona fluorescencja NADH określa ilość NADH w postaci wolnej, związanej z białkiem czy też oba te rodzaje. Problemem jest także określenie komórkowych źródeł pochodzenia NADH: mitochondrialnego, cytozolowego i jądrowego. Zasadniczo NAD(+) i NADH powinny łatwo przechodzić przez pory jądrowe. Z tego względu zmiany stężenia NADH w cytoplazmie wskazują na zmiany stężenia w jądrze. Ponieważ trudne jest rozróżnienie między NADH a zredukowaną formą - fosforanem dinukleotydu nikotynoamidoadeninowego (NADPH) - zwykle oznacza się sumę ilości obu cząsteczek. Obecnie możliwy jest pomiar ilości NADH w naskórku in vivo bez konieczności ekstrakcji tkanek lub komórek. Mechanizm działania takich technik wykorzystuje właściwość pochłaniania przez NADH światła ultrafioletowego (320-380 nm) oraz emisji niebieskiej fluorescencji w zakresie 420-480 nm [19]. Ponieważ NAD nie powoduje fluorescencji, możliwe jest oznaczenie stężenia NADH poprzez monitorowanie absorbancji UV lub wykrywanie niebieskiej fluorescencji [19]. Druga z metod jest wykorzystywana w urządzeniu AngioExpert, które umożliwia pomiar ilości NADH w naskórku [20]. AngioExpert pozwala na oznaczanie dynamicznego stanu NADH w naskórku skóry przedramienia w czasie rzeczywistym, w warunkach in vivo, poprzez ocenę zmian stężenia NADH w czasie w reakcji na zablokowanie (okluzję) przepływu krwi w tętnicy ramiennej za pomocą sfigmomanometru (aparatu do pomiaru ciśnienia krwi), a następnie jego przywrócenie (reperfuzję) [20]. Z technicznego punktu widzenia AngioExpert mierzy fluorescencję cząsteczek NADH wzbudzanych promieniowaniem ultrafioletowym (UV) o długości fali 340 nm (UVB), a maksymalne przenikanie światła 340 nm w naskórku wynosi ok. 0,3-0,5 mm [20]. Z tego względu możliwe jest wykrywanie fluorescencji NADH emitowanej przy $460 \mathrm{~nm}$ (światła niebieskiego) i pomiar NADH w naskórku [20]. Wydaje się, że ponad 90\% sygnału NADH pochodzi z najbardziej zewnętrznej warstwy naskórka, 


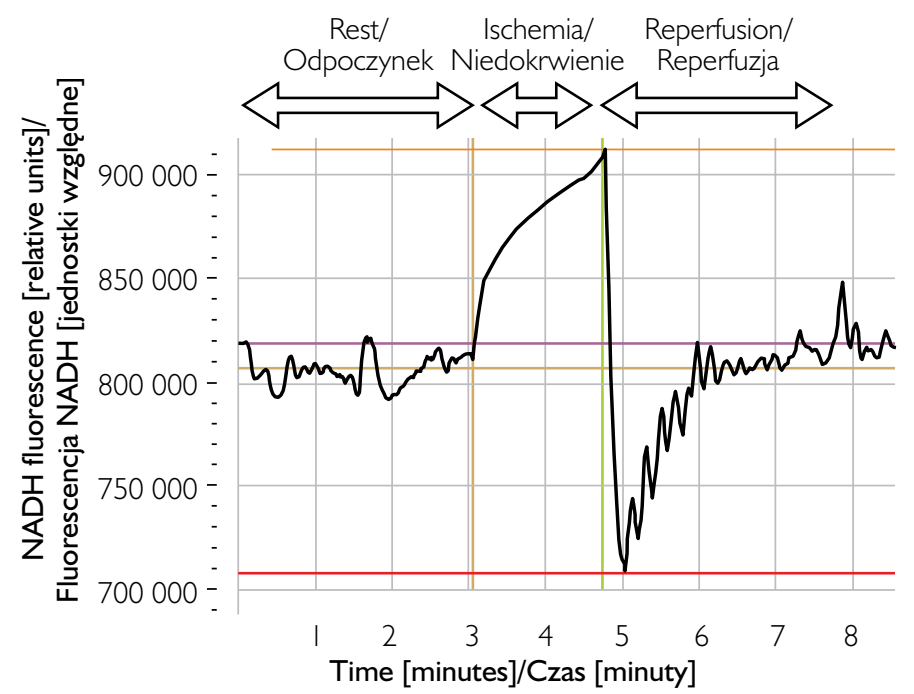

Figure I. Epidermal fluorescence of $\mathrm{NADH}$ recorded in the forearm of a 29-year old woman during rest in seated position followed by 100-second ischemia and subsequent reperfusion

Rycina I. Fluorescencja NADH naskórka zarejestrowana w okolicy przedramienia u 29-letniej kobiety podczas spoczynku w pozycji siedzącej z następującymi po sobie fazami niedokrwienia ( 100 sekund) i reperfuzji

The measurement starts at the rest stage, after which there is an occlusion stage of 100 seconds caused by the blockage of blood flow in the arm artery with the sphygmomanometer (blood pressure meter). The fluorescence rises in the response of ischemia, as a result of the accumulation of NADH in keratinocytes, which is displayed as Ischemic Response area under the curve (IR auc). After sphygmomanometer release, there is a reperfusion stage, in which $\mathrm{NADH}$ fluorescence rapidly decreases within the first few seconds of reperfusion and recovers within 4.5 minutes less steeply to the baseline level. NADH fluorescence is displayed as Hyperemic Response area under the curve (HR auc) [20].

The aforementioned data and the review of a spectrophotometric method in the assessment of NADH fluorescence in real-time, in vivo in the epidermis, shed light on the new aspects of the pathogenesis of psoriasis and point out a new direction of potential application of biophysics in medicine. Thus one can assume that changes in $\mathrm{NAD}(+)$ and $\mathrm{NADH}$ levels in psoriatic keratinocytes can be linked with the pathogenesis of psoriasis, and represent a target for topical usage of nicotinamide-adenine dinucleotide in its therapy.

\section{ACKNOWLEDGMENTS}

This work was supported by the Medical University of Lodz, Poland, Grant no. 503/1-152-01/503-11-002.

\section{CONFLICT OF INTEREST}

The authors declare no conflict of interest. do głębokości 0,1 mm [20]. Typowy poziom fluorescencji NADH naskórka zarejestrowany w okolicy przedramienia u 29-letniej kobiety podczas spoczynku w pozycji siedzącej z następującymi po sobie fazami ischemii (100 sekund) i reperfuzji pokazano na rycinie 1 .

Pomiar rozpoczyna się w fazie spoczynku, po którym następuje etap okluzji (100 sekund) wywołany zablokowaniem przepływu krwi w tętnicy ramiennej za pomocą sfigmomanometru. W reakcji na niedokrwienie, w wyniku nagromadzenia NADH w keratynocytach, rejestrowany jest wzrost fluorescencji przedstawiany jako pole pod krzywą odpowiedzi ischemicznej (IR auc). Po zwolnieniu sfigmomanometru następuje etap reperfuzji, w trakcie którego fluorescencja NADH gwałtownie się zmniejsza w ciągu pierwszych kilku sekund reperfuzji, a następnie w ciągu 4,5 minuty powraca mniej gwałtownie do poziomu bazowego. Fluorescencja NADH przedstawiana jest jako pole pod krzywą odpowiedzi hiperemicznej (HR auc) [20].

Powyższe dane oraz przegląd metody spektrofotometrycznej w ocenie fluorescencji NADH w czasie rzeczywistym w warunkach in vivo w naskórku rzucają nowe światło na zagadnienie patogenezy łuszczycy i wskazują nowy kierunek dla potencjalnych zastosowań biofizyki w medycynie. Można przyjąć, że zmiany stężenia NAD(+) i NADH w keratynocytach w łuszczycy mogą być związane z patogenezą choroby i stanowią cel miejscowego stosowania dinukleotydu nikotynoamidoadeninowego $\mathrm{w}$ terapii tego schorzenia. 


\section{PODZIĘKOWANIA}

Praca powstała przy wsparciu Uniwersytetu Medycznego w Łodzi w ramach grantu nr 503/1-15201/503-11-002.

\section{KONFLIKT INTERESÓW}

Autorzy nie zgłaszają konfliktu interesów.

\section{References}

\section{Piśmiennictwo}

1. Gibbs S.: Skin disease and socioeconomic conditions in rural Africa: Tanzania. Int J Dermatol 1996, 35, 633-639.

2. Danielsen K., Olsen A.O., Wilsgaard T., Furberg A.S.: Is the prevalence of psoriasis increasing? A 30-year follow-up of a population-based cohort. Br J Dermatol 2013, 168, 1303-1310.

3. Griffiths C.E., Clark C.M., Chalmers R.J., Li Wan Po A., Williams H.C.: A systematic review of treatments for severe psoriasis. Health Technol Assess 2000, 4, 1-125.

4. Schön M.P., Boehncke W.H.: Psoriasis. N Engl J Med 2005, 352, 1899-1912.

5. Carrascosa J.M., Tapia G., Bielsa I., Fuente M.J., Ferrandiz C.: Effects of narrowband UV-B on pharmacodynamic markers of response to therapy: an immunohistochemical study over sequential samples. J Cutan Pathol 2007, 34, 769-776.

6. Reich A., Szepietowski J., Adamski Z., Chodorowska G., Kaszuba A., Krasowska D., et al.: Łuszczyca. Rekomendacje diagnostyczno-terapeutyczne Polskiego Towarzystwa Dermatologicznego. Część II: łuszczyca umiarkowana do ciężkiej. Dermatol Rev/Przegl Dermatol 2018, 105, 329-357.

7. Halliday G.M., Damian D.L., Rana S., Byrne S.N.: The suppressive effects of ultraviolet radiation on immunity in the skin and internal organs: implications for autoimmunity. J Dermatol Sci 2012, 66, 176-182.

8. Kuchel J.M., Barnetson R.S., Halliday G.M.: Cyclobutane pyrimidine dimer formation is a molecular trigger for solar-simulated ultraviolet radiation-induced suppression of memory immunity in humans. Photochem Photobiol Sci 2005, 4, 577-582.

9. Rana S., Byrne S.N., MacDonald L.J., Chan C.Y., Halliday G.M.: Ultraviolet B suppresses immunity by inhibiting effector and memory T cells. Am J Pathol 2008, 172, 993-1004.

10. Vodenicharov M.D., Ghodgaonkar M.M., Halappanavar S.S., Shah R.G., Shah G.M.: Mechanism of early biphasic activation of poly(ADP-ribose) polymerase-1 in response to ultraviolet B radiation. J Cell Sci 2005, 118, 589-599.

11. Chang H., Sander C.S., Müller C.S., Elsner P., Thiele J.J.: Detection of poly(ADP-ribose) by immunocytochemistry: a sensitive new method for the early identification of UVB- and $\mathrm{H}_{2} \mathrm{O}_{2}$-induced apoptosis in keratinocytes. Biol Chem 2002, 383, 703-708.

12. Balard B., Giacomoni P.U.: Nicotinamide adenosine dinucleotide level in dimethylsulfate-treated or UV-irradiated mouse epidermis. Mutat Res 1989, 219, 71-79.

13. Anderson K.A., Madsen A.S., Olsen C.A., Hirschey M.D.: Metabolic control by sirtuins and other enzymes that sense NAD+, NADH, or their ratio. Biochim Biophys Acta 2017, 1858, 991-998.

14. Williamson D.H., Lund P., Krebs H.A.: The redox state of free nicotinamide-adenine dinucleotide in the cytoplasm and mitochondria of rat liver. Biochem J 1967, 103, 514-527.

15. Wollina U., Schmidt W.D., Koch A., Scheibe A., Erfurth F., Fassler D.: Fluorescence remission spectroscopy of psoriatic lesions and the effect of topical anthralin therapy. J Eur Acad Dermatol Venereol 2009, 23, 1409-1413.

16. Wozniacka A., Szajerski P., Adamus J., Gebicki J., Sysa-Jedrzejowska A.: In search for new antipsoriatic agents: NAD topical composition. Skin Pharmacol Physiol 2007, 20, 37-42.

17. Zhang Q., Piston D.W., Goodman R.H.: Regulation of corepressor function by nuclear NADH. Science 2002, 295, 1895-1897.

18. Imai S., Armstrong C.M., Kaeberlein M., Guarente L.: Transcriptional silencing and longevity protein Sir2 is an NAD-dependent histone deacetylase. Nature 2000, 403, 795-800.

19. Mayevsky A., Rogatsky G.G.: Mitochondrial function in vivo evaluated by NADH fluorescence: from animal models to human studies. Am J Physiol Cell Physiol 2007, 292, C615-C640.

20. Sibrecht G., Bugaj O., Filberek P., Nizinski J., Kusy K., Zielinski J., et al.: Flow-mediated skin fluorescence method for non-invasive measurement of the NADH at $460 \mathrm{~nm}$ - a possibility to assess the mitochondrial function. Post Biol Kom 2017, $44,333-352$.

Received: 19.07 .2018

Accepted: 19.10 .2018

Otrzymano: 19.07.2018 r.

Zaakceptowano: 19.10.2018 r.

How to cite this article

Bernacka M., Liszewska A., Robak E., Woźniacka A., Bogaczewicz J.: UVB-311 nm phototherapy and NAD(+)/NADH metabolism in keratinocytes in patients with psoriasis. Dermatol Rev/Przegl Dermatol 2018, 105, 710-715. DOI: https://doi.org/10.5114/ dr.2018.80839. 